UDC $338.1 ; 338.2$

\title{
Maintaining the Sustainable Energy Systems: Turning from Cost to Value
}

\author{
U. Ye. Pysmenna ${ }^{1,2)}$, G. S. Trypolska ${ }^{1)}$ \\ ${ }^{1)}$ Institute for Economics and Forecasting, National Academy of Sciences of Ukraine \\ (Kyiv, Ukraine), \\ ${ }^{2)}$ National Technical University of Ukraine "Igor Sikorsky Kyiv Polytechnic Institute" \\ (Kyiv, Ukraine)
}

(C) Белорусский национальный технический университет, 2020 Belarusian National Technical University, 2020

\begin{abstract}
The economies of the world are influenced by the rapidly changing global energy policy agenda. Understanding energy trends implications in the long-term perspective is crucial for responsible and informed sustainability-policy making, with respect to transformations required to enhance the security of energy supply, resource efficiency and affordability, as well to as transformations required to minimize energy poverty and mitigate ecological footprint. Nowadays the price (value) competitiveness of technologies and products as their ability to respond to sustainability demands is becoming the appreciable criterion in choosing the pathways of technological growth or economic strategies designing. The transition to energy sustainability is the so-called quiet energy [r]evolution, or the transition towards $100 \%$ renewable energy supply. Using the sociotechnical transition, vulnerability and sustainable development theories for the assessment of the energy safety level, this article aims to contribute to the understanding of cultural, institutional and innovation prerequisites of sustainable energy transitions. Basing on historical examples, it argues that, despite the cultural dimensions, energy resources and energy mix disparity, geographic location and income per capita, the value instead of cost philosophy in choosing energy pathways maintains the sustainable energy transitions. The key findings are the defined prerequisites of energy transitions sustainability; among them there are cultural dimensions, innovations and the speeds of movement along learning curves when adopting new energy technologies as well as energy policy patterns, applied in a country: value versus cost-driven. The Value vs Cost Energy Policy matrix has been developed in order to determine if a country is sufficiently value-driven in its energy policy.
\end{abstract}

Keywords: energy system, energy transition, energy sustainability, value competitiveness, valuedriven policy, cost-based competitiveness, cost-driven policy

For citation: Pysmenna U. Ye., Trypolska G. S. (2020) Maintaining the Sustainable Energy Systems: Turning from Cost to Value. Energetika. Proc. CIS Higher Educ. Inst. and Power Eng. Assoc. 63 (1), 14-29. https://doi.org/10.21122/1029-7448-2020-63-1-14-29

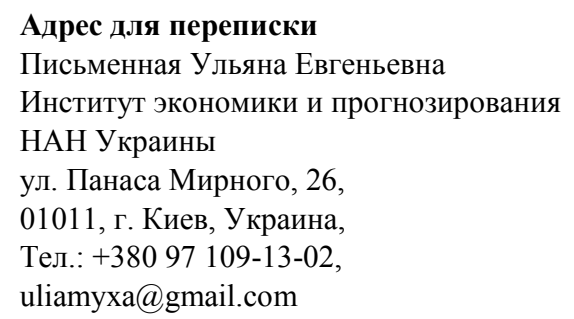

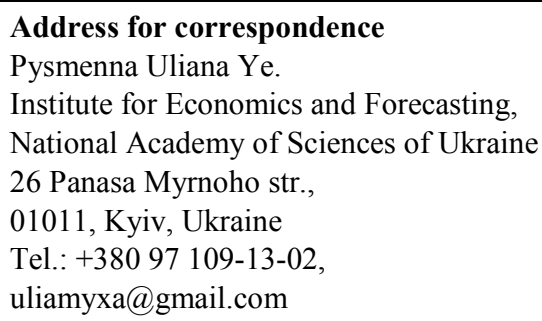




\title{
Обеспечение устойчивого развития энергетических систем: переход от стоимости к ценности
}

\author{
У. Е. Письменная ${ }^{1,2)}$, Г. С. Трипольская ${ }^{1)}$ \\ ${ }^{1)}$ Институт экономики и прогнозирования НАН Украины (Киев, Украина), \\ ${ }^{2)}$ Национальный технический университет Украины «Киевский политехнический институт \\ имени Игоря Сикорского» (Киев, Украина)
}

Реферат. Экономики мира находятся под влиянием быстроменяющейся повестки дня глобальной энергетической политики. Понимание последствий энергетических тенденций в долгосрочной перспективе имеет решающее значение для принятия ответственных и обоснованных решений по вопросам устойчивости в отношении преобразований, необходимых для повышения надежности энергоснабжения, эффективности использования ресурсов и их доступности, а также для нивелирования энергетической бедности и уменьшения негативного воздействия на окружающую среду. В настоящее время ценовая (стоимостная) конкурентоспособность технологий и продуктов в качестве их способности отвечать требованиям устойчивости становится весомым критерием при выборе путей технологического роста или разработки экономических стратегий. Переход к энергетической устойчивости это так называемая «тихая» энергетическая [р]еволюция или переход к 100\%-му возобновляемому энергоснабжению. Используя теории социально-технических трансформаций, уязвимости при оценке уровня энергетической безопасности, а также теорию устойчивого развития, данная статья призвана содействовать пониманию культурных, институциональных и инновационных предпосылок перехода к устойчивой энергии. Основываясь на исторических примерах, мы утверждаем, что, несмотря на культурные аспекты, неравенство в энергетических ресурсах и структуре энергопотребления, географическом положении и размере дохода на душу населения, ценностная, а не стоимостная философия при выборе путей энергетической политики обеспечивает устойчивые энергетические трансформации. Ключевыми результатами является определение предпосылок устойчивости энергетических трансформаций, среди которых: культурные аспекты, инновации и скорость движения по кривым обучения при внедрении новых энергетических технологий, а также шаблоны энергетической политики, применяемые в стране, ценностные против стоимостных. Матрица энергетической политики «ценность против стоимости» разработана с целью определения степени ценностной ориентации энергетической политики той или иной страны.

Ключевые слова: энергетическая система; энергетическая трансформация; энергетическая устойчивость; ценностная конкурентоспособность; ценностно-ориентированная политика; конкурентоспособность, основанная на стоимости; политика, основанная на стоимости

Для цитирования: Письменная, У. Е. Обеспечение устойчивого развития энергетических систем: переход от стоимости к ценности / У. Е. Письменная, Г. С. Трипольская // Энергетика. Изв. выси. учеб. заведений и энерг. объединений СНГ. 2020. Т. 63, № 1. С. 14-29. https://doi.org/10.21122/1029-7448-2020-63-1-14-29

\section{Introduction}

Over the last two decades, the sustainable energy trend, being an important prerequisite of sustainable economy, has been embracing more and more countries and regions of the world. Wind and solar photovoltaic sources globally became the fastest growing sources of electricity. The energy access slowly expands. The growing energy needs in fast growing countries are accompanied 
by green investments enhancement in these countries. Ecologic and climate concerns are forcing a plenty of global players of energy markets to redesign their energy systems and energy balances by means of sustainable energy transformations. However, the sustainable energy trend faces challenges all over the world, but its density differs in a great way.

The primacy factor of energy transitions is often considered to be energy policy that, in turn, is considered as a compromise of interests of global players (countries, supranational formations or regional energy systems). Thus, the energy policy as the "direction of actions, accepted and restrained by governments" [1], can be entirely determined by geopolitics, i. e. by conformities of distribution and redistribution of spheres of the different states and interstate associations. The growing influence on energy politics of "transnational governance networks involving non-state actors" should also be considered. This influence would increase in the future and could take many forms [2].

IEA defined the following directions of world energy system development: a) meeting of growing world demand on energy after growing profits and population of developing countries; b) providing of access to energy for low-income part of the planet's population; c) reaching the aims of climate change mitigation, particularly the enhancement of renewables deployment [3]. However, with the strengthening of integration processes, the efficiency of energy systems as the ability to provide goods and services in environmentally sound way at reasonable price is more and more based not on the efficiency within the limits of the country economy, but on the compromise of interests of totality of energy systems and energy markets of some countries, non-state intergovernmental or supranational institutes.

The changes in world energy regional structure are accompanied by the increase of the clean energy ratio as well as the increase of number of countries, whose domestic supply ratio by an energy resource is less than $20 \%$ and/or decreasing promptly. The influence of regional energy disproportions on large regions and developing countries creates the growing dependence on import of energy resources and enhance resource competition. The tendencies of providing the increase of demand and sustainable import of energy resources in the world, the instability of energy prices form the considerable challenge for the most world economies. As a result, the introduction of new resource bases and transit facilities changes a geographic structure and world energy markets rules, viz. the regions of production and consumption, strategic supply pathways of energy resources, demand and supply disparity, legal and organizational principles of markets functioning. Such increasing tension makes a challenge to the performance of energy transitions towards sustainable energy systems [4]. And there is a need to understand the prerequisites of sustainable energy transitions.

The aim of this paper is to consider energy transitions in terms of the values they serve, which is a more comprehensive way of viewing them than only a cost-benefit analysis. 


\section{The main part}

Acknowledging to sociotechnical transition theory [5] we can consider energy policies and strategies (action plans of their implementation) as energy transitions management. This includes: establishing prerequisites for their appearance; their speeding up/slowing down, protecting existing ones; minimizing negative externalities and social vulnerabilities of sociotechnical regimes changes; maintaining optimal energy mix. Under such consideration, the success or failure of policy implementation greatly depends on the differences in energy transitions performance (the first key factor). Cherp et al. [6] stated that the differences in performance of energy transitions (which are divided by three types, viz. techno-economic, socio-technical and political) in different countries could be explained by the performance of five mechanisms: a) states working with incumbents for secure supply/demand balance; b) regimes gaining/losing strengths from energy resources and infrastructure dynamics; c) regimes selfreproduction through vested political interests; d) states nurturing niches as a parallel strategy; e) cross-border technology diffusion and niche innovation.

Some researchers, e. g. Coenen, Benneworth \& Truffer [7], make explicit transition geographies, stressing the importance of regional factor of transitions development. Thus, they also speak about the need of understanding the international, translocal nature of transition dynamics. Moreover, in the comparative analysis of energy transitions of key countries fulfilled by Hauff, Bode, Neumann \& Haslauer [8] the "global energy transitions" vs "country pattern transitions" are discussed. They emphasize that despite the fact that the reasons, management, development pathways, threats and perspectives of transitions greatly differ from country to country, the main characteristics and processes being "amazingly similar" in many countries.

Along with the performance, the second key factor of energy transitions management is the vulnerability of energy systems under the influence of externalities, caused by energy transitions. Externalities are not necessarily negative, being the part of the economic transaction concerned and emerging outside the transaction. The vulnerability is "the exposure of vital energy systems to risks" [2]. Even sustainable transitions are often being postponed, slowed down or rejected to avoid negative externalities that could threaten the energy system stability. The special policy measures to avoid negative externalities of energy transitions are needed. For example, the 2016 increased shutdown of French nuclear power units, accompanied by the coal- and oil-fueled power plants closure has decreased base load capacity. In order to maintain the security of supply in the energy transition, the state has to launch its capacity market [9].

Basing on sociotechnical transition theory, an energy transition is claimed to be the energy-related sociotechnical regime shift. The question is how the sociotechnical regime shift could be measured. Obviously, energy systems can be estimated by the number of indexes: capacity, reserves, ecological impact, by the structure of "fuel mix" etc. [10]. The energy policy of a country on a number of energy resources or technologies can be defined by the dynamics 
of the set of indexes, such as: the structure of energy generation by technologies, volumes of investments, volumes of subsidies, income by the types of activity, rent volumes, barriers etc. However it complicates for the estimation or modeling of energy transitions.

The third key factor of the managing of energy transitions is how much the energy transition management leads to the change of energy sustainability level, or the sustainability of energy transitions. The sustainability transitions generally are described as the transitions that adapt societies and economies to sustainable modes of production and consumption [7, 11, 12] (Coenen \& Diaz Lopez, 2009; Coenen, Benneworth \& Truffer, 2012; Turnheim, Berkhout, Geels, Hof, McMeekin, Nykvist, \& van Vuuren, 2015). Also given are the common examples of a sustainability transition: the decarbonization of energy and transport systems, biodiversity and food security transitions, waste or water management and urban development.

The question is could every transition towards the sustainable modes of energy production, transformation and consumption (aka energy balance) be marked as an energy sustainability transition. The energy sustainability Trilemma (energy security; energy affordability; ecological sustainability), annually published by World Energy Council (WEC), ranged countries by Energy Sustainability Index (ESI) [13]. If an energy transition performance maintains the rise along all three axes of Trilemma and the negative externalities are overcome by positive ones in a way that the overall score grows, that is an energy sustainability transition. Therefore, the transition to energy stability is a primary change in at least one parameter of the energy balance, which is sufficient to cause a shift in the sociotechnical regime, leading to the overall effect of the rise within the Trilemma of energy stability Trilemma.

WEC points out the similarities and the differences between first 10 ESI topranked countries. Among the similarities are: high GDP income per capita, OECD membership, postindustrial, service-based economies, more than $25 \%$ share of low- and zero-carbon power generation technologies [13]. The differences are sufficient: energy mix, energy import dependence and reserves levels, nuclear power share, geographic location. Is the economic welfare of a country is necessary and enough to form the sustainable energy system? Or is the energy sustainability the "engine" of economic welfare and overall sustainability? By answering these questions, we aim to find out the prerequisites of energy sustainability.

Cultural dimensions. Maintaining the sustainability is known to be the balancing between social welfare, economic growth and ecological imprint. When speaking about the energy sustainability, we often mention sustainable energy consumption and sustainable energy life style or behavior that has cultural roots. Seeking for the cultural prerequisites for energy sustainability we compared ESI top, middle and low-ranked countries' cultural dimensions (Fig. 1a), using G. Hofstede cultural dimensions theory [14] and the energy sustainability dimensions [13]. 


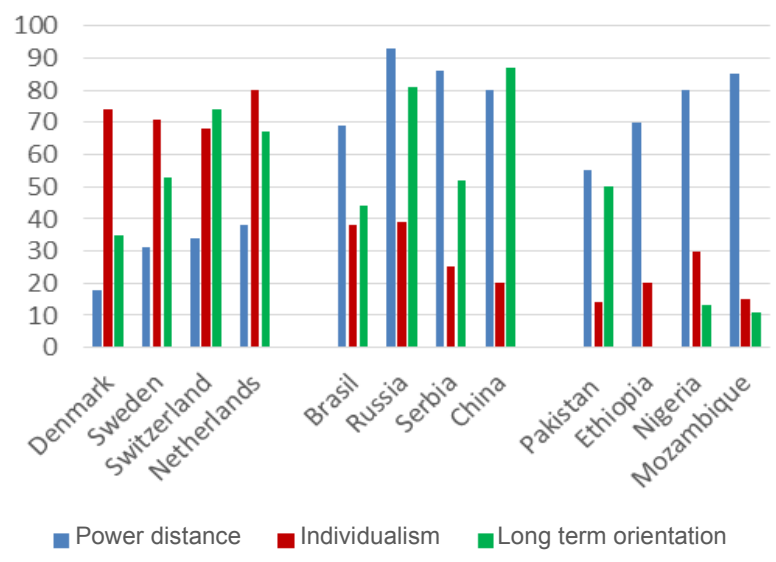

b

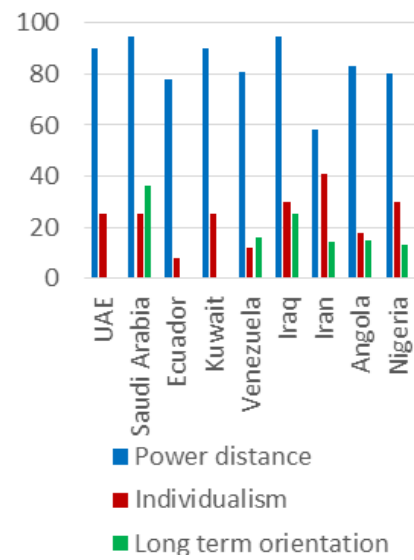

Fig. 1. Selected Hofstede cultural dimensions (power distance; individualism; long term orientation): a - 10 ESI top-, 4 middle- and 4 low-ranked countries; b - OPEC countries (based on 2018 ESI and 2018 Hofstede publications) [13, 14]

The comparative analysis points out that high ESI rank of a country is accompanied by the achievement of high level of individualism and at least one of two other dimensions: low power distance or high long-term orientation.

Why does high individualism have relation to the energy sustainability? As G. Hofstede stated, "in societies with collectivism, common aims and welfare are placed higher than personal ones" [14]. However, any of ESI top-ranked countries has not high collectivism cultural dimension. The individualism level above the middle helped them to form the societies with huge middle class and low corruption. In terms of an energy system, this gave the prerequisites for the development of highly effective energy systems with sufficient demand side management, Smart Grid and high ratio of individual and middle-capacity power units.

Low power distance is described as the following: "people strive to equalize the distribution of power and demand justification for inequalities of power" [14]. This helps to establish the effective institutional structure and operation of governmental and non-governmental institutions, which maintain the sustainable energy goals achievement. Among the ESI top-ranked countries only France has the power distance index higher than the mid-level (68 out of max 120 points).

High long-term orientation means achieving long-term goals and values results highly. Such time horizon view helps to meet the needs of a generation without harming the next generations' ability to meet their needs. This characteristic ensures the vision of energy technology perspectives with the consideration of the fossil fuels limited nature and the need of ecological sustainability. Despite that, from the general point of view, this cultural parameter seems to be primarily important for maintaining the sustainable energy; its high level does not in itself guarantee high energy sustainability. For example, China and Russia both have high level of long-term orientation (87 and 81 points 
respectively), but also have high power distance (80 and 93) and, the most important, their individualism is rather low (20 and 39). Other cultural characteristics (masculinity/femininity, uncertainty avoidance index; indulgence/restraint) seem not to have the significant influence on ESI ranking.

From multi-level perspective (MLP) point of view on transitions [5], high level of individualism prepares a ground for niche-innovations. Low level of power distance helps to generate effective institutions. This prevents the blocking and postponing of socio-technical landscape development by different political lobbies, and then such development pressures the existing sociotechnical regime and creates opportunity windows for novelties. Long-term perspective view via expectations and networks enhances the external influences on niches resulting in the socio-technical regime shift.

Fig. $1 \mathrm{~b}$ shows that OPEC countries, with their Hofstede dimensions similar to low-ranked countries, are placed mostly in the middle of ESI rank, due to their high energy security level. Rich resource base and high GDP favor the possibilities to maintain the constituents of energy sustainability, but do not guarantee it. After Michael Porter, more important is not the current stock of factors of a nation, but the "rate end efficiency" or the intensity of their creation (or reimbursement), upgrade and deployment [15]. And nowadays in some ESI middle-ranked countries, e. g. in Saudi Arabia and Indonesia, such intensity is rising towards the sustainable goals. The increasing energy demand and low oil prices forced Saudi Arabia to declare plans to develop almost $10 \mathrm{GW}$ of renewable energy by 2023 with up to USD 50 bln investments to substitute 80,000 barrels of oil in domestic consumption [16]. Indonesia, forced with demographic MLP growth, shows the progress being the first among 20 fast-moving countries in energy access enhancement with $4.3 \%$ annual rate [17]. So, despite the cultural prerequisites and material resources disparity of different countries of the world, their energy policies could enhance Porter's "rate end efficiency of factors", that leads to more efficient, secure and ecologically sustainable energy systems.

Innovations and movement along learning curves. Energy transitions are not always innovation transitions. Do the energy sustainability transitions always deal with innovations or could we solve the Trilemma and considerably enhance energy security, energy affordability and ecological sustainability without novelties? Or such enhancement could be maintained only by extensive change of energy mix and deployed energy technologies parity? The analysis of the efficiency of energy policies proves that the considerable enhancement of Trilemma is not possible without the innovation transitions [18-21].

Renewable energy technologies are among the best examples of energy innovations. Renewables in general provide prospects of lower GHG emissions, jobs creation, technological improvements, but some negative externalities as well (such as structural unemployment, difficulties in maintaining of the loadgeneration balance, the increase of a power system electricity prices due to the feed-in tariffs and some other). Environmentally friendly technologies at their early stages of deployment have higher prices than conventional energy technologies, thus subsidies and other forms of support are needed to make environmentally friendly technologies viable. 
Numerous studies [22-24] indicate that that early technology adoption brings larger cost reduction in the long run. Over time technologies become more mature, producers and users gain experience, economy of scale takes place, and the level of direct and indirect support diminishes. Understanding of importance of new technologies, measured by the level of direct financial and indirect support by means of well-tailored regulatory energy policies, make countries not only cost-driven, but also value-driven.

Let us consider some aspects of technology adoption. Such a consideration makes us to apply to the learning curves. The concept of the learning curve, in its turn, is a measure of cost decline for every doubling of capacity or of energy output. The "learning curve" is a concept that describes the relationship between cost and experience over a defined period [24]. The learning curve is used to measure production efficiency and to forecast costs. The Learning Curve Model states that for each doubling of the total quantity of items produced/ installed, costs decrease by a fixed proportion, the corresponding change in price is a Progress ratio (Investopedia, 2019). In other words, learning curves show the degree of technological developments spread. Understanding learning effects is important to design sufficient support schemes [25], i. e. different learning rates may result in refining support rates based on technology type. This, in its turn, might affect the very structure of energy system of the country. For many renewable energy sources, the learning factor varies between 0.11 and 0.95 (for more mature technologies). A learning factor 0.9 means that costs will $10 \%$ decline when cumulative installed capacity increases twofold [26]. The learning rate equals 100 minus a Progress ratio [27].

The largest number of learning rates studies so far has focused on photovoltaics and onshore wind power plants. In case of renewables, one should bear in mind that there is difference in industry producing equipment for renewables and renewable electricity/heat. The first one could be easily traded in open economics, while export/import of renewable electricity/heat is more difficult to trace. Learning effects can be easier traced in case of new technologies, than for existing technologies, because in order to reach the significant price reductions the latter need to increase installed capacities in order of terawatts. That is why the mean learning rate for coal technologies is $8.3 \%, 15 \%$ for natural gas turbines, negative to $6 \%$ for nuclear power plants [28].

In accordance with IEA, learning effect lead to decreasing of wind turbines cost globally by a factor of 4 since 1980s, whereas since 2004 until 2007 they have increased by $20-80 \%$ in different countries because of high commodity prices and insufficient turbines output. After 2007, the learning rate has acelerated, and most of the progress in wind turbines is attributed to increase in turbine size [29].

Modern renewable energy technologies show great possibilities for cost reduction, especially in case of photovoltaics, by improving the materials for modules output, transiting from crystalline silicon to dye sensitive solar cells and thin films. 
In 2015, International Technology Roadmap for Photovoltaic (ITRPV) stated that global PV module capacity at the end of 2015 was $60 \mathrm{GW}$, and the PV learning rate was $21 \%$ globally, which indicated high rate of technical learning. The average crystalline-silicon PV module price declined from USD 0.62/W in 2014 to USD $0.58 / \mathrm{W}$ in 2015 , which corresponds to manufacturing capacities of $39.3 \mathrm{GW}$ in 2014 and $50 \mathrm{GW}$ in 2015 [9]. This learning factor for solar PV remained relatively stable within the last 30 years in the majority of countries where solar PV is employed, whereas for wind power plants it varied between 0.75 in the UK and 0.95 in Germany. Rubin et al. [30] defines the average learning rate of $23 \%$ for the PV in 1959-2011.

The installed capacity of wind farms globally was $539.2 \mathrm{GW}$ (Global Cumulative Installed Wind Power Capacity from 2001 to 2017) [31]. Growing demand for wind farms led not to the market expansion, but to supply constraints and slowing the market growth by 2014. Rapid market growth started in 2015, growing up to $10 \mathrm{GW}$ annually worldwide [26]. The average learning rate for both onshore and offshore wind farms was $12 \%$ [28].

For biomass-based electricity generation the learning rates was $11 \%$, in particular in case of fluidized bed combustion for combined heat and power and for biogas output it was also $11 \%$. For specific bioenergy crop (sugarcane, corn, and rapeseed) production the average learning rate was $32 \%$. For hydroelectric technology the learning rate was $1.4 \%$ [28]. However, Rubin et al. [30] states that the developed countries such as USA have already used their sites for hydroelectric, thus this technology has a good potential of deployment in developing countries. For geothermal technology, there is no single learning rate, as this technology is largely dependent on-site characteristics (temperature, chemical content of geothermal fluid etc.)

Ocean energy is an important, highly potential and predictable source of energy without GNG emissions. There are several types of technologies allowing obtaining energy from waves, tides and currents. Now the cost of energy varies between 11-80 eurocents/(kW/h). The learning factor was projected to be $10-15 \%$ for offshore wave and 5-10\% for tidal stream [26].

Energy storage nowadays exists in a form of large pumped hydropower and small industrial and commercial installations of battery storage. Large pumped hydropower had a capacity of $149 \mathrm{GW}$ globally in 2014, whereas small installations had a cumulative capacity of 5 GW in 2014. In 2015-2016 and onwards, both significant technological improvements, installation of new capacities as well as regulatory policy developments took place. Since 2010, global learning rate for lithium-ion based technology in e-vehicles and electronics reached $22 \%$. Developed countries with liberalized energy markets are encouraging the emergence of new storage technologies as a means of decentralizing energy supply and developing additional service markets, such as capacity or frequency markets.

In order to make RES technologies viable, significant investments are needed. According to IEA, there are so called "learning investments", i. e. "additional costs for the technology compared with the cost of the same service from 
technologies which the market presently considers cost-efficient" [27]. Governmentfunded RD\&D usually make the part of these learning investments, which directly affects the level of the countries innovation profiles. Environmentally friendly technologies such as RES obtain financial support even for initially expensive technologies which otherwise would not be deployed without considerations for climate change mitigation (by means of feed-in tariffs, carbon taxes, obligations and quotas etc.).

There are studies showing that technology development and diffusion are global, thus no national boundaries are needed to define learning effects [32, 33]. However, the rate of increase of learning factor varies even between neighboring countries, as well as the cost of technologies. Above mentioned learning factor for wind power plants varies between 0.75 in the UK and 0.95 in Germany [26]. The first wind power units in UK were deployed in 1951, but only in 2007 along with $20 \%$ renewables EU policy they began to raise significantly. In Germany this technology was introduced much later, but with Energiewende it has developed amazingly from $55 \mathrm{MW}$ in 1990 to $27 \mathrm{GW}$ in 2010 and $50 \mathrm{GW}$ in 2016. The cost of renewable energy technologies in France has been coming down over the past few years, but not as fast as in other EU countries due to, inter alia, the stable nuclear socio-technical regime [9].

The earlier an energy technology has been introduced in a country and the more intensively its capacity has been installed, the faster is the movement along learning curve. And it is the matter of an energy policy and value consciousness.

Value-driven vs cost-driven policies. In the XXI century, in the context of the competition between energy resources, energy technologies, between the producers of energy products within an energy technology and, at last, between energy policies, the impact of non-cost and non-price criteria becomes more and more determinative. It is rather a value competition. When a country's energy policy envisages more cost-intensive but also more widely applicable energy access strategy, based on domestic and renewable resources, which would enhance the energy security, this strategy is more value-driven. When someone chooses the most energy-efficient, low-emission and socially responsible aircooling technology instead of the cheapest one, this is also the case.

Value competition is a form of non-price competition that envisages a gaining not as the quantitative gaining (e. g. cost and income), but as the integrity of quantitative, qualitative and cost parameters of a technology or a product, which format its impact on the sustainability. The competition based on values differs from Michael Porter's competition based on innovations, because it is not always innovation-based but always sustainability-based. The Indonesian Kerosene to Liquid Propane Gas Conversion Program, Bolivian exploration of new natural gas resources and the natural gas to solid and biomass fueled boilers replacement in a number of gas-dependent countries are far not novelties introduction but all of them are energy sustainability improvements.

The competing technologies or products are compared not by their unique value, but by their sustainable value, i. e. their ability to impact on the sustainability. 
Based on this, we can understand that value-oriented energy policies, value competitive energy technologies and energy products are those that can meet the requirements of sustainable development.

Let us look at how countries choose their energy transition paths depending on their geopolitical role. The belonging of a country to a group of countries with common geopolitical interests determines its energy policy and strategy. For considering of such belonging it is sufficient to use the matrix division of countries after primary methods of providing the collective energy security, that are concentrated on three basic groups of countries and regions after the dominant type of activity: producers (net exporters), consumers (net importers) and countries - transmitters of energy resources and on three basic groups of countries after geopolitical belonging (Tab. 1).

Table 1

Matrix of balance of interests and energy policy of world energy market participants

\begin{tabular}{|c|c|c|c|}
\hline $\begin{array}{l}\text { The group } \\
\text { of countries }\end{array}$ & $\begin{array}{l}\text { OECD } \\
\text { countries }\end{array}$ & OPEC countries & $\begin{array}{l}\text { Countries, which are not } \\
\text { OECD and OPEC members }\end{array}$ \\
\hline \multirow[t]{2}{*}{$\begin{array}{c}\text { Net } \\
\text { exporters }\end{array}$} & \multicolumn{3}{|c|}{$\begin{array}{l}\text { Development of standby hydrocarbon production capacities. } \\
\text { Preservation of national sovereignty and control of the strategic resources. } \\
\text { Consolidation on strategic export markets, providing of guarantees of sustainable } \\
\text { demand on exported energy resources. } \\
\text { Provision of investments in the development of resources production and infra- } \\
\text { structure. } \\
\text { Diversification of energy resources export markets. } \\
\text { Obtaining of shares of distributing and transport companies abroad. } \\
\text { Provision of reliable and uninterrupted transport and transit of exported energy } \\
\text { resources at reasonable prices. } \\
\text { Provision of security of energy infrastructure. } \\
\text { Search of an adequate level of energy investments impact on economy } \\
\text { and optimal volumes of energy resources export. } \\
\text { Decrease of energy intensity and providing of large-scale modernization } \\
\text { of productive funds with mass introduction of energy saving technologies } \\
\text { both from production and demand side }\end{array}$} \\
\hline & \multicolumn{2}{|c|}{$\begin{array}{l}\text { Achievement of balanced and economically } \\
\text { reasonable price policy concerning energy products, } \\
\text { that provides the return of investments and } \\
\text { moderate norm of income, however such that does } \\
\text { not conduce to substantial reduction of demand }\end{array}$} & $\begin{array}{l}\text { Maximization of exported } \\
\text { hydrocarbons cost }\end{array}$ \\
\hline \multirow[t]{2}{*}{ Transmitters } & \multicolumn{3}{|c|}{$\begin{array}{l}\text { Selection of reservoirs (deposits) for storage of reserves of hydrocarbons with } \\
\text { the special legal state and special mechanism of bringing in to exploitation. } \\
\text { Provision of capital and financing of investments in a transit infrastructure. } \\
\text { Provision of safety of transit infrastructure }\end{array}$} \\
\hline & - & - & $\begin{array}{l}\text { Maximization of transit rent } \\
\text { and cost of hydrocarbons } \\
\text { storage services }\end{array}$ \\
\hline
\end{tabular}


End Tab. 1

\begin{tabular}{|c|l|l|l|}
\hline $\begin{array}{c}\text { The group } \\
\text { of countries }\end{array}$ & \multicolumn{1}{|c|}{$\begin{array}{c}\text { OECD } \\
\text { countries }\end{array}$} & \multicolumn{1}{|c|}{$\begin{array}{c}\text { Countries, which are not } \\
\text { OECD and OPEC members }\end{array}$} \\
\hline $\begin{array}{c}\text { Net } \\
\text { importers }\end{array}$ & $\begin{array}{l}\text { Development of standby hydrocarbon production capacities. } \\
\text { Meeting the demand on imported energy, the guarantees of sufficient supply of } \\
\text { energy resources in a prospect. } \\
\text { Provision of energy infrastructure security, reliability and uninterruptness of energy } \\
\text { supplies. } \\
\text { Obtaining of production and supply control over energy resources from other } \\
\text { countries. } \\
\text { Diversification of energy products supply, diversification of their transportation } \\
\text { routes and variety of their suppliers. } \\
\text { Diversification of fuel and energy balances due to the development of production } \\
\text { of domestic (first of all renewable) energy resources. } \\
\text { Flexibility of production, reduction of energy intensity due to the introduction } \\
\text { of new technologies to decrease the dependence on the import of energy resources, } \\
\text { the development of market mechanisms of energy efficiency stimulation. } \\
\text { Provision of financing, mobilization of investment and new technologies } \\
\text { in the development and functioning of infrastructure. } \\
\text { Gradual liberalization and development of competition on energy markets } \\
\text { and markets of constrained services }\end{array}$ \\
\hline & $\begin{array}{l}\text { Political stability } \\
\text { of suppliers }\end{array}$ & $\begin{array}{l}\text { Provision of people's basic needs in energy resources, forming of } \\
\text { active demand on the energy sector services }\end{array}$ \\
\hline $\begin{array}{l}\text { Stabilization of } \\
\text { energy resources } \\
\text { prices at accep- } \\
\text { table level for } \\
\text { support of } \\
\text { economy com- } \\
\text { petitiveness }\end{array}$ & $\begin{array}{l}\text { Balancing of price politics } \\
\text { in relation to energy resources } \\
\text { at acceptable level for support } \\
\text { of competitiveness of the } \\
\text { economy }\end{array}$ & $\begin{array}{l}\text { Provision with cheap energy } \\
\text { resources for attaining } \\
\text { maximum economy growth }\end{array}$ \\
\hline
\end{tabular}

As it was mentioned above, rich resource base, favorable geographic location and high income favor the possibilities to maintain the energy sustainability, but do not guarantee it. Being in a one of the cells of the balance of interests matrix forms the energy policy pattern of a country, but with the value extent. The extent to which a country's energy policy depends on cost retains its position in the following matrix, the Cost and vs Value Matrix of energy policy (Tab. 2).

The value-driven energy policies maintain the equable movement towards multiple sustainable goals, with simultaneous measures to overcome negative externalities of transitions. Germany, facing the need to compensate backup capacities during a period of energy transition to more than $50 \%$ share of decentralized power generators by 2033 , decided to redesign the electricity market structure and maintain the financing of larger-scale generation capacity to keep the optimal level of system security. Also, Germany shared some reserve capacities between transmission system operators in order to reduce system reserve requirements. The clear visibility of the need of fast development of renewables 
in France comes from their possible contribution to reduce the share of nuclear energy from $78 \%$ to $50 \%$ by 2025 . But it also needs the substantial redesigning of power market and the investments into energy storage capacities.

Cost vs Value Energy Policy Matrix (energy policy patterns)

\begin{tabular}{|c|c|c|}
\hline & Cost & Value \\
\hline 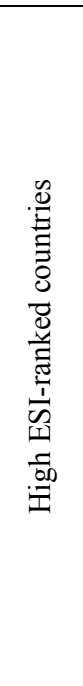 & $\begin{array}{l}\text { Short-term economic profitability of energy } \\
\text { transitions is a mandatory condition (e. g. } \\
\text { France). } \\
\text { Higher-cost energy imports is replaced by } \\
\text { domestic carbon-intensive technologies } \\
\text { (e. g. UK) }\end{array}$ & $\begin{array}{l}\text { Equable movement towards multiple } \\
\text { sustainable goals, with simultaneous } \\
\text { measures to overcome negative } \\
\text { externalities of transitions. } \\
\text { Dynamic and flexible energy investment } \\
\text { policies. } \\
\text { Carbon prices and commitments are } \\
\text { meaningful signals. } \\
\text { Energy market is able to provide secure } \\
\text { supply and demand to utilize high-priced } \\
\text { but low-carbon and renewable energy } \\
\text { resources and comparatively high-LCOE } \\
\text { energy technologies. } \\
\text { Fast moving along energy technologies } \\
\text { learning curves. } \\
\text { Regional and supranational interests } \\
\text { on energy markets rather than domestic: } \\
\text { solidarity principle }\end{array}$ \\
\hline 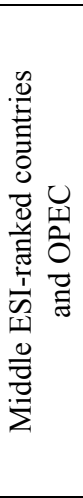 & $\begin{array}{l}\text { Stabilization of energy prices at acceptable } \\
\text { level to support the economy. } \\
\text { Energy subsidies slow down energy efficien- } \\
\text { cy progress. } \\
\text { Renewables are weakly penetrating TPES. } \\
\text { High entry costs prevent new energy markets } \\
\text { entrants. } \\
\text { Energy markets liberalization and deregula- } \\
\text { tion are slowed down or postponed because } \\
\text { of instable energy prices externality concerns. } \\
\text { Maximization of exported energy resources } \\
\text { prices instead of market coupling and integra- } \\
\text { tion (OPEC) }\end{array}$ & $\begin{array}{l}\text { Understanding the need of strong support } \\
\text { of renewables to reduce of the nuclear } \\
\text { and fossil fuels share. } \\
\text { Attaining the progress in the rate towards } \\
\text { the achievement of sustainable energy } \\
\text { goals and commitments, while the potential } \\
\text { is still huge. } \\
\text { The progress in moving along energy } \\
\text { technologies learning curves differs } \\
\text { between countries and depends on } \\
\text { the transfer of technologies }\end{array}$ \\
\hline 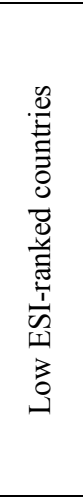 & $\begin{array}{l}\text { Provision of cheap energy resources for } \\
\text { attaining maximum economic growth. } \\
\text { Maximization of exported energy resources } \\
\text { prices instead of market coupling and } \\
\text { integration. } \\
\text { Cost savings vs energy efficiency. } \\
\text { High costs of doing business for distributed } \\
\text { generation, which influences energy access. } \\
\text { No/small progress in moving along energy } \\
\text { technologies learning curves because of late } \\
\text { start and slow rates of deployment. } \\
\text { Postponing the achievement of the declared } \\
\text { sustainable energy goals and commitments }\end{array}$ & $\begin{array}{l}\text { Domestic interests on energy markets } \\
\text { rather than regional and supranational. } \\
\text { Expanding the energy access } \\
\text { in the demographic growth concerns }\end{array}$ \\
\hline
\end{tabular}




\section{Main results and discussion}

The value-driven energy policy should envisage dynamic and flexible investment policies for renewables, as well as for highly demand and frequency responsible conventional power plants, and storages (for example, support policies for renewables in China, Germany etc.) Energy storages development is highly investment-intensive and needs energy policies able to reduce investment risks. The special energy storages funding programs are bundled with decentralized and renewable power generation development programs (e. g. in Germany), tax credits for the battery, kinetic, compressed air and hydro pumped storages operators (e. g. in the USA).

Understanding the importance of early adoption of sustainable energy technologies encourages countries to support the ease of implementation and development of such technologies. The value-driven energy policy in many countries provided faster movement along learning curves and guaranteed the decrease of LCOE comparatively to common technologies in a short and medium term.

The innovation-based energy policies form the considerable transition from cost to value competitiveness, becoming the ground for domestic novelties. Some innovation growth programs are itself the action plans for achieving sustainable development in 3 dimensions: economical, ecological and social by means of: establishing knowledge resources (universities), complementing a biased industrial structure towards diversification, business-to-business and universities-to-business cooperation, etc. (good example is the Swedish innovation doctrine). The development of knowledge in industrial and commercial sectors (problem-oriented university research) is a so-called "third assignment" for universities after education and research. The demand on energy-related novelties mainly comes from the large energy utilities, but the demands placed by global competition are also increasing the need for small and medium-sized energyrelated companies to cooperate with universities and research institutions.

\section{CONCLUSIONS}

1. To contribute to the understanding of cultural, institutional and innovation prerequisites of sustainable energy transitions we addressed to F. Geels' sociotechnical transition theory and considered energy policies as energy transitions management. It envisages: establishing prerequisites for their appearance; their speeding up/ slowing down, protecting existing ones; minimizing negative externalities and social vulnerabilities of sociotechnical regimes changes; maintaining optimal energy mix. We defined three key factors of the efficient energy policy as an energy transitions management: energy transitions performance, vulnerability of energy systems under their externalities and their influence on the energy sustainability.

2. Acknowledging to G. Hofstede cultural dimensions theory and data, we found that high Energy Sustainability Index rank of a country is accompanied by the achievement of high level of individualism and at least one of two other cultural dimensions: low power distance or high long-term orientation. 
3. We defined value-driven energy policies as those which are able to respond to the sustainability demands. It also has been shown, that, despite the different cultural prerequisites and material resources disparity of different countries of the world, their value-driven energy policies could enhance Porter's "rate and efficiency of factors" and lead to more efficient, secure and ecologically sustainable energy systems. The extent of how much a country's energy policy is value-driven maintains a country's position in the Cost vs Value Energy Policy Matrix.

\section{Abbreviations:}

WEC - World Energy Council; ESI - Energy Sustainability Index; MLP - multilevel perspective; GHG - greenhouse gas; ITRPV - International Technology Roadmap for Photovoltaic; IEA - International Energy Agency; PV - photovoltaic; RD\&D research, development and demonstration; RES - renewable energy sources; COE levelized cost of electricity.

\section{REFERENCES}

1. Kilievich O. (1999) State Policy Analysis: Microeconomic View. Part 1. Modern Economic Theory and State Finances. Kyiv, National Academy for Public Administrationunder the President of Ukraine (in Ukrainian).

2. Cherp A., Jewell J. (2014) The Concept of Energy Security: Beyond the Four As. Energy Poicy, 75, 415-421. https://doi.org/10.1016/j.enpol.2014.09.005.

3. IEA/OECD (2012) World Energy Outlook 2012: Executive Summary. Available at: https://ru. scribd.com/document/124814693/IEA-World-Energy-Outlook-2012. (Accessed 12 February 2019).

4. Potapenko V., Podolets R., Mukhin V. (2013). Organizational and Economic Mechanisms of Balance of Interests in the Energy Sector of Ukraine. Efektivna Ekonomika [Efficient Economics], (11). Available at: http://www.economy.nayka.com.ua/?op=1\&z=2451. (Accessed 30 December 2019) (in Ukrainian).

5. Geels F., Schot J. (2007) Typology of Sociotechnical Transition Pathways. Research Policy, 36 (3), 399-417. https://doi.org/10.1016/j.respol.2007.01.003.

6. Cherp A., Vinichenko V., Jewell J., Suzuki M., Antal M. (2017) Comparing Electricity Transitions: a Historical Analysis of Nuclear, Wind and Solar Power in Germany and Japan. Energy Policy, 101, 612-628. https://doi.org/10.1016/j.enpol.2016.10.044.

7. Coenen L., Benneworth P., Truffer B. (2012) Toward a Spatial Perspective on Sustainability Transitions. Research Policy, 41 (6), 968-979. https://doi.org/10.1016/j.respol.2012.02.014.

8. Hauff A., Bode D., Neumann F., Haslauer F. (2014) Global Energy Transitions. A Comparative Analysis of Key Countries and Implications for the International Energy Debate. Berlin, Weltenergierat - Deutschland, 30.

9. International Energy Agency (2016) Next Generation Wind and Solar Power. Full Report. Paris. https://doi.org/10.1787/9789264258969-en.

10. Araujo K. (2014) The Emerging Field of Energy Transitions: Progress, Challenges, and Opportunities. Energy Research \& Social Science, 1, 112-121. https://doi.org/10.1016/j.erss. 2014.03.002.

11. Coenen L., Diaz Lopez F. J. (2009) Comparing Systems Approaches to Innovation and Technological Change for Sustainable and Competitive Economies: an Explorative Study into Conceptual Commonalities, Differences and Complementarities. Journal of Cleaner Production, 18, 1149-1160. https://doi.org/10.1016/j.jclepro.2010.04.003.

12. Turnheim B., Berkhout F., Geels F., Hof A., McMeekin A., Nykvist B., van Vuuren D. P. (2015) Evaluating Sustainability Transitions Pathways: Bridging Analytical Approaches to Address Governance Challenges. Global Environmental Change, 35, 239-253. https://doi.org/10. 1016/j.gloenvcha.2015.08.010.

13. World Energy Council (2018) Energy Sustainability Trilemma Index 2018. Available at: https://www.worldenergy.org/assets/downloads/World-Energy-Trilemma-Index-2018.pdf. (Accessed 30 December 2019). 
14. Hofstede Insights. Country Comparison. Available at: https://www.hofstede-insights.com/countrycomparison. (Accessed 10 February 2019).

15. Porter M. (1990) The Competitive Advantage of Nations. Harvard Business Review, MarchApril, 73-91.

16. Dipaola A. (2017) OPEC's Top Producer is Turning to Wind and Solar Power. Bloomberg. Available at: https://www.bloomberg.com/news/articles/2017-02-14/saudis-warm-to-solar-asopec-s-top-producer-aims-to-help-exports. (Accessed 30 December 2019).

17. International Energy Agency (2015) Energy Policies Beyond IEA Countries: Indonesia 2015. Energy Policies Beyond IEA Countries. Paris, IEA, https://doi.org/10.1787/9789264065277-en.

18. Dearing A. (2000) Sustainable Innovation: Drivers and Barriers. Available at: https://www.oecd. org/innovation/inno/2105727.pdf. (Accessed 30 December 2019).

19. Mulder K. F. (2007) Innovation for Sustainable Development: from Environmental Design to Transition Management. Sustainable Science, 2 (2), 253-263. https://doi.org/10.1007/ s11625-007-0036-7.

20. International Energy Agency (2000) Experience Curves for Energy Technology Policy. Paris, IEA. https://doi.org/10.1787/9789264182165-en.

21. International Technology Roadmap for Photovoltaic (ITRPV) (2017) Results 2016, Including Maturity Report. https://www.worldfutureenergysummit.com/_media/libraries/products/A493 E2 AF-5056-B73B-0D765674956C42F6-pdf.pdf.

22. Mattsson N., Wene C. O. (1997) Assessing New Energy Technologies Using an Energy System Model with Endogenized Experience Curves. International Journal of Energy Research, 21 (4), 385-393. https://doi.org/10.1002/(sici)1099-114x(19970325)21:4<385::aid-er275>3.0.co;2-1.

23. Goulder L., Mathai K. (2000) Optimal $\mathrm{CO}_{2}$ Abatement in the Presence of Induced Technological Change. Journal of Environmental Economics and Management, 39 (1), 1-38. https://doi. org/10.1006/jeem.1999.1089.

24. Nordhaus W. D. (2009) The Perils of the Learning Model for Modeling Endogenous Technological Change. https://doi.org/10.3386/w14638.

25. International Energy Agency (2016) Energy Technology Perspectives 2016. Towards Sustainable Urban Energy Systems: Executive Summary. https://doi.org/10.1787/energy_tech-2016-en.

26. Canton J., Johannesson Linden A. (2010) Support Schemes for Renewable Electricity in the EU. Economic Papers 408. Available at: https://ec.europa.eu/economy_finance/publications/ economic_paper/2010/pdf/ecp408_en.pdf. (Accessed 3 January 2020).

27. Kagan J. (2019) Learning Curve. Investopedia. Available at: http://www.investopedia.com/ terms/1/ learning-curve.asp\#ixzz4WmWb9fM0. (Accessed 10 February 2019).

28. Greenpeace International, Global Wind Energy Council Solar Powereurope (2015) Energy [R] evolution. A Sustainable World Energy Outlook 2015. $100 \%$ Renewable Energy for all. Available at: https://www.duesseldorf.greenpeace.de/sites/www.duesseldorf.greenpeace.de/files/ greenpeace_energy-revolution_erneuerbare_2050_20150921.pdf. (Accessed 3 January 2020).

29. IEA/OECD (2008) Renewable Energy Essentials: Wind. Available at: https://www.iea.org/ reports/renewable-energy-essentials-wind. (Accessed 3 January 2020).

30. Rubin E., Azevedo I., Jaramillo P., Yeh S. (2015) A Review of Learning Rates for Electricity Supply Technologies. Energy Policy, 86, 198-218. https://doi.org/10.1016/j.enpol.2015.06.011.

31. The Statistics Portal. Global Cumulative Installed Wind Power Capacity from 2001 to 2018 (in Megawatts). Statista. Available at: https://www.statista.com/statistics/268363/installedwind-power-capacity-worldwide/. (Accessed 10 February 2019).

32. Junginger M., Faaij A., Turkenburg W. (2005) Global Experience Curves for Wind Farms. Energy Policy, 33 (2), 133-150. https://doi.org/10.1016/s0301-4215(03)00205-2.

33. Chazov E. L., Grakhov V. P., Krivorotov V. V., Simchenko O. L. (2019) Improving the Efficiency of Planning as a Basis for Management the Investment Activity of an Industrial Enterprise. Energetika. Izvestiya Vysshikh Uchebnykh Zavedenii $i$ Energeticheskikh Ob'edinenii $S N G=$ Energetika . Proceedings of the CIS Higher Education Institutions and Power Engineering Associations, 62 (1), 88-100. https://doi.org/10.21122/1029-7448-2019-62-1-88100 (in Russian).

Received: 26 September 2019 Accepted: 28 November 2019 Published online: 31 January 2020 